\title{
Bakhtin on the Nature of Dialogue: Some Implications for Dialogue between Christian Churches ${ }^{1}$
}

\author{
DUNCAN REID \\ Melbourne College of Divinity
}

\begin{abstract}
The paper offers a contribution to the discussion of the role of intercultural issues in dialogue between Christian churches representing differing doctrinal positions. It argues that ecumenical dialogues have in the past focused on doctrinal issues at the expense of cultural differences, which may be just as significant in the relationships, including understandings and misunderstandings, between churches. It proposes that expertise on intercultural communication be also part of ecumenical dialogue. This argument shall be developed in several stages: first, a discussion of belief statements as cultural artefacts; second, a discussion of a recent study of the dynamics of intercultural communication, a study that draws on Bakhtin's concept of dialogue; and finally the proposal for the application to ecumenical dialogue of the study's methodological approach to intercultural communication.
\end{abstract}

Keywords: Mikhail Bakhtin, Belief, Communication, Culture, Doctrine, Ecumenism

Dialogue between Christian churches, or ecumenical dialogue - at least on the level of the official dialogues conducted by small delegations appointed as representatives of their own churches - usually takes the form of theological discussion that seeks to find 'common ground' (Oppegaard \& Cameron 2004, 249-68) or at least 'growing consensus' (Meyer 1991; Veliko \& Gros 2005) between two or more churches on the basis of doctrinal statements. Usually the focus is on highly technical differences of either language or

1 A shorter version of this paper was presented at the Orientale Lumen Conference for Australia and Oceania, which met in Melbourne under the auspices of the Australian Catholic University, 4-7 July, 2012. I am very grateful to the following scholars who read drafts of the manuscript and offered constructive comments and advice: Dr Phillip Tolliday of Charles Stuart University (on theology), Dr Carine Cools of the University of Jyväskylä (on intercultural communication theory), Dr Jonathon Clarke of the University of Melbourne (on Bakhtin), and Dr Marion Maddox of Macquarie University (on the Hindmarsh Island case). Any errors, oversights or misinterpretations are mine alone. 
opinion in the past, the aim being to find doctrinal commonality underlying the divergence. These conversations about technical issues almost invariably have their origins in intercultural encounters, which may or may not develop into the discussion of belief statements. And though intercultural encounter often plays an important part in formal ecumenical dialogues, its role is often not formally acknowledged.

The disadvantage of the major emphasis in ecumenical dialogue focussing on resolving doctrinal difference is first, that it takes cognizance of only one aspect of church life, viz. the doctrinal, and second, that dialogue around this aspect is not immediately accessible to the vast majority of church members, and in fact seems irrelevant to them and their daily concerns, including their daily intercultural encounters. The purpose of this paper is to propose that discussion of doctrinal questions needs to be complemented by a parallel discussion of intercultural questions. To this end I propose using a particular methodology in intercultural communication developed by Carine Cools, on the basis of earlier work by L. A. Baxter and B. M. Montgomery and making substantive reference to the work of the Russian philosopher, literary critic and semiologist Mikhail Bakhtin. Cools developed her version of 'relational dialectics' to explore the relationships of intercultural couples living in Finland, generally of one Finnish partner and one partner of a different cultural background. I propose that this method could be extended to apply to ecumenical dialogue, to form a methodological bridge between two discipline areas: ecumenical theology and intercultural communication. The hope is that such a bridge may in time facilitate greater mutual understanding between churches and their theological traditions. It may in time be extended to the 'wider ecumenism' (Ariarajah 2006) of dialogue between religions and religious communities, but here, in the interests of brevity and relative simplicity, I confine myself to intra-Christian (ecumenical) dialogue. Examples cited will be taken from my own Australian context. The term 'doctrine' will be used here to indicate officially endorsed teachings of churches; 'belief statements' to indicate a slightly broader category of religious claims inclusive of, but not identical with, doctrine. 'Ecclesial communities' can be taken to refer to specific churches, 'faith communities' more broadly to communities holding certain beliefs in common.

The idea of applying the insights of intercultural communication theory to ecumenical dialogue is by no means a new. It was advocated at the 1970 World Council of Churches 'Seeing Education Whole' conference, and received additional emphasis from the influence of the Brazilian educator 
Paulo Freire on the WCC between 1980 and 1990 (Strümpfel 2010). But considerable progress has been made since then in intercultural communication theory, and in any case, the message deserves to be repeated at a time when there seems to be a retreat from ecumenical endeavour (Tolliday 2010, 265). I shall develop my proposal on the understanding that both doctrinal discourse and intercultural communication discourse are second-order cultural artefacts built on the foundations of a first-order level of communal experience and praxis. In the case of belief statements, including doctrine, this is second-order or meta-level discourse aimed at explaining coherently the collective experiences of the community of believers, in this case Christian believers. In the case of intercultural communication theory, it is second-order discourse aimed at explaining coherently the experiences of human beings (or groups of human beings) attempting to negotiate a variety of relationships with other human beings across the boundaries of culture and language.

\section{Belief Statements as Cultural Artefacts: an Australian Example}

In the early 1990s, plans were lodged to build a bridge linking Hindmarsh Island at the mouth of the Murray River in South Australia with the mainland. Members of the local Ngarrindjeri Aboriginal community objected on the grounds that the waters surrounding Hindmarsh Island were of religious significance as traditional secret women's business, and to link the island to the mainland would compromise its character as an island, and consequently its religious significance. Some other members of the same Aboriginal community, including some so-called 'dissident' Ngarrindjeri women, objected that they themselves had never heard of any such sacred traditions. (It has been suggested that this group may have been concerned about the compatibility or otherwise of traditional beliefs with Christian doctrine.) This objection led to the claim by non-Indigenous people, specifically the financiers of the proposed bridge and a journalist, that the secret-sacred tradition must therefore be a 'fabrication', aimed at blocking development. This led to a Royal Commission, called to consider whether the secret women's business, or any part of it, was fabricated.

Marion Maddox, who has examined the evidence in detail, has pointed to what she sees as significant methodological flaws in the whole process, a process that in other respects went to considerable lengths to ensure sensitivity to local Aboriginal values, beliefs and sensibilities (Maddox 2005, 120-39). The central question was a religious question, whether the secret women's 
business was or was not a fabrication, but no religious studies expert was called to give evidence. Maddox challenges the simplistic understanding of the nature of religious belief operative in the workings of the Commission. The Commission never entertained the possibility, according to Maddox, that all statements of religious belief may be, in some sense, fabrications; all may be, in other words, cultural artefacts - a point that would not be disputed by contemporary theologians when considering, say, the wording of the Nicene Creed or the text of St Mark's Gospel. Further, Maddox points out, to recognise a belief statement as a cultural artefact need in no way diminish the regard or veneration with which a community holds that belief. Meanwhile, two federal inquiries and a federal court case concluded that the women's business was not fabricated. In the decision by Justice John von Doussa, the court case distinguished between a long-standing cultural tradition and a self-conscious and purposeful fabrication put together for some extrinsic end.

Doctrine can be understood as an expression of culture. In what has come to be seen as a major contribution to post-liberal or post-modern theological method (Plantinga 2010, 569-70), George Lindbeck proposes what he calls a cultural-linguistic model of doctrine, in which theological statements function as 'regulative statements' (Lindbeck 1984, 17). Lindbeck contrasts this model to what he calls the propositionalist-cognitivist and the experiential-expressivist models of doctrine, representing in terms of Lindbeck's own Lutheran tradition the neo-orthodox and the liberal tendencies. ${ }^{2}$ In his cultural-linguistic model, for Lindbeck 'the function of church doctrines that becomes most prominent $[\ldots]$ is their use, not as expressive symbols or as truth claims, but as communally authoritative rules of discourse, attitude, and action' (Lindbeck 1984, 18). A similar point was made independently by Dietrich Ritschl, another theologian who emphasizes the regulative nature of theological discourse, proposing the term 'regulative axiom' for statements that are accepted forms of speech within a given community and which govern the way language is used (Ritschl 1986). The subject matter of theology, according to Ritschl is not God, but talk about God, so that theological mistakes refer not to ontological errors, but to mistakes in the use of language and its rules. Once again the point is that regulative axioms are what we could call cultural artefacts.

Lindbeck is pointing to a culturally constructed framework through which to understand reality. More comprehensively, Lindbeck describes this approach in these terms:

2 These terms can also be taken to correspond to Jürgen Moltmann's dialectic of identity and relevance, which I have discussed elsewhere in relation to inter-religious dialogue (Reid 2012). 
A religion can be viewed as a kind of cultural and/or linguistic framework or medium that shapes the entirety of life and thought. It functions somewhat like a Kantian a priori, although in this case the a priori is a set of acquired skills that could be different. It is not primarily an array of beliefs about the true and the good (although it may involve these), or a symbolism expressive of basic attitudes, feelings, or sentiments (although these will be generated). Rather, it is similar to an idiom that makes possible the description of realities, the formulation of beliefs, and the experiencing of inner attitudes, feelings, and sentiments. Like a culture or language, it is a communal phenomenon that shapes the subjectivities of individuals rather than being primarily a manifestation of those subjectivities. (Lindbeck 1984, 33.)

Against the expressive-experiential model, Lindbeck accepts the primacy of beliefs, but without the excessive intellectualism that often accompanies a propositional approach to doctrine (Lindbeck 1984, 35). Time and again Lindbeck emphasizes the idea of socialisation into a belief system: 'To become religious involves becoming skilled in the language, the symbol system of a given religion' (Lindbeck 1984, 34). As with language, one cannot be 'religious' in general any more than it is possible to speak 'language in general'. Rather, just as we speak specific languages, we act (or fail to act) and believe (or disbelieve) in ways specific to our culture:

To become religious [...] is to interiorize a set of skills by practice and training [...]. The primary knowledge is not about the religion, nor that the religion teaches such and such, but rather how to be religious in such and such ways. (Lindbeck 1984, 35.)

Being religious means, then, that one knows a particular set of 'codes' (or grammar) from within, and one can use these codes or this grammar intuitively to inform experience.

Lindbeck's approach may seem unduly relativistic, except that his approach does not try to find some deeper unity underlying all belief systems. Without wanting to explore Lindbeck's system in depth, the important things for our purpose is that he presents religious belief as what we could call a cultural artefact, and that this in no way minimises the significance of such belief. Lindbeck's proposal can be seen as a post-liberal attempt to re-unite the diverging strands of the modern 'dissociation of sensibility', the divergence of head (propositional-cognitive) and heart (expressivist-experiential) which emerged, according to Andrew Louth, in the 12th century western 
European separation of academic theology from mystical praxis, and grew into an absolute opposition with the Romantic movement by the late 18th century (Louth 1983, 1-16). Lindbeck's approach attempts both to transcend and to unite these destructively divergent tendencies.

Lindbeck is careful to point out that there is nothing in his culturallinguistic model that requires the rejection (or acceptance, for that matter) of epistemological realism and a correspondence theory of truth. The difference between the propositional-cognitivist approach and Lindbeck's own preferred model is that in the former, doctrinal statements are first-order propositions (about reality), where in the latter, they are second-order propositions governing how religious language is to be used within a particular tradition. Lindbeck notes the regulative nature of doctrinal statements in the patristic period, arguing that this element is lost only with the emergence of scholasticism, which certainly views doctrinal statements as regulative, but only because they are seen as ontologically, and therefore also propositionally, true (Lindbeck 1984, 105).

\section{Culture}

The foregoing discussion begs the question as to what constitutes culture, and here, as indicated above, I rely on the recent work of Carine Cools. Among the many attempts to define culture (and an adequate exploration of this, as well as the related concept of 'community', is well beyond the limits of the current article), Cools offers a definition particularly suited to the present discussion in that it emphasizes the dynamic, intercultural elements:

Culture is not considered a static set of norms and values (materialised in artefacts and behaviour) within or for a specific group or nation or state, but as the dynamic social or group capacity to find solutions to recurrent societal needs and standard problems. Culture is interactively produced and reproduced in the perception, understanding and formation of reality. It creates an intercultural discourse that shapes a common cognitive ground, facilitates exchanging ideas, knowledge sharing, and mutual learning. Thus discourse about intercultural encounters has ceased merely presenting and contrasting difference and has become a way of analyzing the dynamic relationship between communication, language and culture, and of examining the way mutual understanding is achieved in discourse and the emergence of discursive interculture. (Cools 2011, 23.) 
Here culture is to be understood through a consideration of what she calls the dialectics of communication. If, as argued above, doctrinal statements are cultural artefacts, then these will also be subject to the pressures of cultural, and intercultural, interaction. Applying this conceptual framework to couples, partnerships of two individuals in an intercultural relationship, Cools identifies a complex of contradictions. The central dialectic is between stability and change, as this relates to degrees of certainty and uncertainty between individuals in a couple partnership. It can be seen to take place in two directions: internally (within the relationship between the partners), where one partner inevitably wants more stability (certainty or predictability) than the other at a given time; and externally (in the couple's relationship as a couple vis-à-vis their world or the social context in which they live), where either the social context will require more stability (certainty or conventionality) of them than they want, or vice versa.

Secondary to this central dialectical pairing of 'stability - change' are the related conceptual spheres of 'integration - separation' and 'expression - privacy'. These refer, in one direction, to differing levels of integrations and separations both internally (between the dialogue partners themselves) and externally (between the partnership and their social context), these tendencies finding expression as connection and autonomy (within the relationship) and as degrees of inclusion in the world and seclusion from the world (on the part of the partnership). In the other direction, partnerships are characterised by degrees of expression and privacy, taking the forms of openness and closedness (within the relationship), and of revelation and concealedness about the dynamics of the relationship (in relation to the outside world).

This can be shown diagrammatically thus:

\section{Diagram 1}

\begin{tabular}{|l|l|l|l|}
\hline & Integration -Separation & Stability -Change & Expression -Privacy \\
\hline $\begin{array}{l}\text { Internal (within } \\
\text { the relationship) }\end{array}$ & connection - autonomy & $\begin{array}{l}\text { predictability - nov- } \\
\text { elty }\end{array}$ & $\begin{array}{l}\text { openness - closed- } \\
\text { ness }\end{array}$ \\
\hline $\begin{array}{l}\text { External (rela- } \\
\text { tionship vis-à-vis } \\
\text { world) }\end{array}$ & inclusion - seclusion & $\begin{array}{l}\text { conventionality - } \\
\text { uniqueness }\end{array}$ & $\begin{array}{l}\text { revelation - con- } \\
\text { cealedness }\end{array}$ \\
\hline
\end{tabular}


For the purpose of her study, Cools adapts the theory of what she calls 'intercultural relational dialectical forces' (Cools 2011, 225-36). Here a relational dialectics framework identified in speech communication is brought into an intercultural context, to include both the 'regular' relational dialectical theory of speech communication, and also experienced relational tensions of an intercultural nature. This theory details some of the forces (or pressures, as I would prefer to call them) that tend to build up around individuals in intercultural couple relationships. Where Cools uses this framework to interpret the dialogue between partners and their social networks in intercultural couple relationships, I am suggesting we extend it to address the intercultural complexities in the dialogue between churches. In the case of ecumenical dialogue partners, the stability-change dialectic may refer to particular church constituencies, whose attitudes can range from openly hostile towards the dialogue process to impatient that progress is not made more quickly. This can be seen as differing manifestations of the dialectic of separation-integration. Further, such pressures can find expression outwardly and publicly, in the course of the dialogue (expression), and inwardly, within the memberships of the delegations (privacy).

It is Cools' extension of this model to intercultural relationships through the use of the dialogical thought of Mikhail Bakhtin that strikes me as offering the most innovative potential contribution to ecumenical dialogue. Bakhtin was the first to explore literature, especially the novel, by applying to it the phenomena of everyday speech. Cools is not alone in reversing this process by bringing Bakhtin's literary insights back into the domain of everyday speech, to shed light on the nature of speech between individuals of different cultural backgrounds in couple partnerships. I am not aware, however, of these insights having yet been extended to ecumenical dialogue.

\section{Bakhtin and the Role of Everyday Speech}

Bakhtin's thought gives the impression of being highly unsystematic, though this is to a greater or lesser extent due to the chaotic circumstances under which he worked. Several major works have been lost, and others exist only in damaged or incomplete versions. But we should also respect the deliberately and intrinsically unsystematic nature of Bakhtin's work, and avoid the tendency to reduce it to a simple linear logic. Cools' analysis shows this respect by bringing Bakhtin to bear on real-life dialogues, and also succeeds in drawing some order out of this seemingly chaotic system, indicating four elements in Bakhtin's thought that she deems relevant to 
intercultural communication. For current purposes it seems best to take these elements in the opposite order from the way Cools presents them.

First, at the most basic level, utterance takes the form of what Bakhtin calls 'heteroglossia' (literally, otherness of tongue or language). Dialogue is comprised of discrete utterances, and utterances are the links in chains of dialogue. An utterance consists of taking the words of others and filling them with our own content, bending them to fit our own purposes. Thus there can be no unadulterated word, independent of context. Bakhtin expresses this point quite poetically:

Only the mythical Adam, who approached a virginal and as yet verbally unqualified world with the first word, could really have escaped from start to finish this dialogic inter-orientation with the alien word that occurs in the object. Concrete human discourse does not have this privilege. (Bakhtin 1981, 279. $)^{3}$

Bakhtin's term 'heteroglossia' thus locates the basic condition governing meaning in any utterance, so that context takes primacy over text (or utterance). There is an intertextuality, or complex of relationships between utterances, that, if not acknowledged from the outset, may bring the dialogue undone:

To study the word as such, ignoring the impulse that reaches out beyond it, is just as senseless as to study psychological experience outside the context of that real life toward which it was directed and by which it is determined (Bakhtin 1981, 292). ${ }^{4}$

Second, there is the significance of the ever-changing context in which utterance takes place. Every dialogue, for Bakhtin, is performed in the context of a specific, unique and unrepeatable time (chronos) and place (topos), which he calls its 'chronotope', and the specific details are obvious only in the particularities of that chronotope or time-place context. Bakhtin draws

3 Тольқо мифический Адам, подошедший с первым словом к еще неоговоренному девственному миру, одинокий Адам, мог действительно до конца избежатъ этой диалогической взаимоориентации с чужим словом в предмете. Конкретному историческому человеческому слову этого не дано. (Bakhtin 1975, 92.)

4 Изучать слово в нем самом, игнорируя его направенность вне себя, - так же бессмысленно, как изучать психическое переживание вне той реальности, на которую оно направлено и которою оно определяется (Bakhtin 1975, 105). 
explicitly here on the, at the time, relatively new discipline of quantum physics with its postulation of time as contiguous with space (Bakhtin 1975, 121). This influence means that neither place nor time is privileged, but both are interdependent. Chronotope refers then to the qualitative aspect of time and place as it affects dialogue in all its forms.

The discussion of chronotope includes and gives particular priority to the carnival-like (or 'carnivalesque') element. We exist, that is to say, in the borderland between our own consciousness and others' consciousness of us; and we drop in and out of conversations. The conversation itself is never begun or ended, only our participation in it. Carnival denotes the quality of time or state of being in which normal conventions are suspended. This suspension of the normal gives rise to liminal, or boundary, situations that can in turn lead to breakthrough experiences in understanding. Understanding takes place in these marginal states. In the lives of individuals, it is rites of passage which have the structure 'separation - margin - re-integration' that are carnival-like, out of the ordinary occasions, marking a change in status or identity. In the lives of ecclesial or more broadly religious communities, the public celebration of moments of change in relationship may be as important as the preparation leading up to these moments.

Third, dialogue is characterised by unfinalisability, or open-endedness. Truth is not something to be found in any final sense, so cannot be the outcome of either/or thinking (in which one speaker is right and the other therefore wrong). This also means there can be no finally valid or definitive set of contradictions (or pairs of dialectical opposites), because conflicting pressures and tendencies are always multiple, varied and changing within the context of the moment. These tensions constitute, in Bakhtin's thought, the 'deep structure' of all human experience.

Fourth, as the highest or emergent level of the analysis, social life takes the character of dialogue: it is dialogical, or multi-vocal, involving two or more voices. 'Polyphony' is the term used by Rowan Williams for this quality of language identified by Bakhtin (Williams 2008). Dialogue begins with the encounter of self and other. A dialogue (in the novel) is for Bakhtin 'a system of languages that mutually and ideologically interanimate one another' (Bakhtin 1981, 47). ${ }^{5}$

5 Язык романа - это система диалогически взаимоосвещающихся языков (Ваkhtin 1986, 358). I would prefer to translate 'mutually interanimate' here as 'mutually illumine', as взаимоосвещающихся is a cognate of свет 'light', a word rich with theological and religious connotations. 
For Bakhtin, the self is constructed in dialogue with the other, and vice versa, so dialogue is the process of becoming who we are. Further, dialogue contains both centripetal and centrifugal forces or tendencies: centripetal forces of unity (seeking commonality), and centrifugal forces of difference (asserting separate identity). Bakhtin draws attention away from sharp dualistic opposites, and confronts us with the need to engage with the ongoing complexities of how words, and the identities that emerge from them, have been partially shared in the past and will continue to be shared into the future. For it is in dialogue that we come up against Bakhtin's 'chronotope of threshold', the boundary that either changes us or fails to change us - or perhaps better, that changes us, but in an either positive or negative way, and always unpredictably.

This analysis of Bakhtin prompts Cools to move away from 'neat dialectical pairs' (Cools 2011, 226), preferring to speak of 'intercultural relational dialectical forces' (Cools 2011, 225-35) that impact upon the internal communication of intercultural couples. She goes on to outline the difficulties and - also, but sometimes not so obvious - delights of 'adaptation' of one party to the other. It is essential to note here that adaptation has nothing to do with assimilation ${ }^{6}$ or homogenisation: it has to do with ongoing interaction in dialogue.

Related dialectically with identity is marginality. Marginality is about exclusion (including self-exclusion), but can take differing forms. There can be an encapsulated marginality, the sense of being stuck (what we call marginalisation) between cultures, of never feeling at home. This sense of displacement, and its associated sense of Unheimlichkeit, the uncanny anxiety of not feeling 'at home', has been explored by Edward Casey (1993, ix-xi, 34). ${ }^{7}$ There can also be a constructive marginality, the positive sense of standing on a threshold, a point of creativity, and this comes from understanding one's own marginality in order both to define boundaries where necessary, and also to feel at home anywhere. So marginality can be suffered as marginalisation or chosen as a state of empowering and liberating liminality. This is the 'liminality of belonging', at which point individuals either belong (together), or fail (Cools 2011, 209-10).

6 'Assimilation' in the Australian context carries a particular significance in the history of relations between Indigenous and non-Indigenous peoples, referring to a period in which government policy was to 'assimilate' the former to the culture of the latter, thus actively extinguishing Indigenous cultures.

7 We might also refer here to the massive sense of displacement felt by Australian Aboriginal peoples over the past two centuries, a sense undoubtedly exacerbated by the fact that Aboriginal ontology is arguably essentially place-based rather than time-based (Swain 1993). 
Where Cools applies this analysis of Bakhtin to dialogue between individuals, it should not surprise us that ecumenical dialogue can be characterised by contrasting tendencies to connect with the other and also, often at the same time, to separate from the other by asserting the distinctiveness of our particular community. Bakhtin rejects the dualistic notion that one must 'go native' and discard one's own background to understand a new culture, and proposes instead that a culture is only fully revealed through the eyes of the other, the representative of the other cultural tradition. Therefore, the intersubjectivity of a positive dialogical encounter provides both parties with a more profound understanding of their own respective cultures (Cools 2011, 38). This also describes the potential for churches to grow together, but also the potential for failure.

\section{Ecumenical Dialogue: An Australian Example}

In 2001 the Anglican-Lutheran dialogue in Australia produced the Common Ground Agreed Statement (Oppegaard \& Cameron 2004, 249-68). The dialogue committee had several overseas dialogues to draw on, specifically the Meissen Agreement (1988), the Porvoo Agreement (1992), and the AnglicanMoravian Fetter Lane Agreement (1996). But each of these was only partially relevant: each arose out of and spoke to a very specific context of church life and historical conditions in the relationships between the churches in conversation. The 160-year shared history of Anglicans and Lutherans in Australia lent elements to this local dialogue that were unique, and so a uniquely Australian discussion, and resulting document, were needed. This can be taken as an example of context, the specifics of time and place, taking priority over text.

Added to this, the dialogue needed to take cognisance of changes in selfperception on the part of both churches over time. The Anglican Church of Australia, for example, was known until 1962 simply as the Church of England, no formal distinction being made from the state church in England, even though it had never been the state church in Australia or, prior to federation, in any of the self-governing Australian colonies. Most non-Aboriginal Australians still regarded themselves as regional British at the time of federation in 1901 (Malouf 2001, 89), with Australian Anglicans maintaining this emotional link with the 'mother country' till well after other legal and diplomatic changes had made it a thing of the past. In 1962 a new constitution renamed the church the 'Church of England in Australia', the name 'Anglican Church of Australia' not being formally adopted till 1981. This was well after Austral- 
ian citizens (a concept that had not existed in law till 1948) had ceased to be designated British subjects. The changing name of the church represents a gradually changing self-perception on the part of the majority of Australian Anglicans as they grew into their identity as Australian rather than English or British, and as the Anglican Communion underwent a parallel change in identity from a predominantly ethnically, linguistically and culturally English ecclesial body to a worldwide, multicultural body. This is a process that still continues. Any 'closure', for the theoretical reasons that Bakhtin has shown, is, and ultimately always will be, illusory. The practical point is that this process of cultural change has to be taken into account by members of other churches, in this case the Lutheran Church of Australia, in any dialogue - official or unofficial - they conduct with Australian Anglicans. And, of course, vice versa.

The above example illustrates the role of chronotope and unfinalisability in a particular dialogue. The role of heteroglossia and polyphony could also be explored in this, though such an exploration would touch more on the technical theological language of both traditions, especially where the same term ('real presence' comes to mind as an example) is used but with possibly different significances. As a participant in the Anglican - Lutheran conversations, I can report that the whole process of dialogue was characterised by a careful attention to the nuances of terminology. That is to say, each technical term that went into the final agreed statement had been discussed at length and examined for its various possible meanings and implications. Bakhtin would warn us that even this degree of care may minimise, but will never totally exclude, the possibility of future misunderstanding.

\section{Conclusion: Bakhtin and Ecumenical Dialogue}

Cools has demonstrated how Bakhtin's insights can fruitfully be brought to bear on the complexities of relationships between individuals from differing cultural backgrounds. My suggestion is that these insights are just as relevant to differing ecclesial (and more widely, faith) communities. Where Bakhtin says 'the language of the novel is a system of mutually illuminating dialogical languages' (Bakhtin 1986, 358) ${ }^{8}$, we could, at the risk of being presumptuous, adapt this to read: 'the language of ecumenical conversations is a system of mutually illuminating dialogical languages'.

Bakhtin himself offered some thoughts on how his insights might apply to dialogue about matters of faith:

8 Язык романа - это система диалогически взаимоосвещающихся языков. 
All religious systems, even primitive ones, possess an enormous, highly specialized methodological apparatus (hermeneutics) for transmitting and interpreting various kinds of holy word (Bakhtin 1981, 351). ${ }^{9}$

This he placed in contrast to the language of science, which aims at 'mastery over mute objects, brute things, that do not reveal themselves in words, that do not comment on themselves' (Bakhtin 1981, 351). ${ }^{10}$

Further, if this insight is not taken into account, ecumenical dialogue is at best impoverished and at worst blocked, for 'we only become', as Cools puts it, 'through the other' (Cools 2011, 203). We only become, that is to say, who we are, and this is always 'about negotiating, which always means having to give something up while gaining something else' (Cools 2011, 204).

The proposal here, then, is that in ecumenical dialogue we expand the current preferred method (loosely designated as seeking 'common ground' or 'growing consensus'), through the dialectics of stability and change, especially with regard to doctrinal statements, to take account of the dialectic of intercultural communication. Common ground may well still be the ultimate aim, and seeking may be the process, but this proposal would represent a refinement in the method of seeking such common ground. Another way of putting this is to think of a transition between two paradigms for both understanding and conducting ecumenical dialogue. The current paradigm emphasizes a state of conflict and assimilation moving toward union, which will implicitly involve varying degrees of conflict and agreement, inclusion and seclusion, revelation and concealment - in other words, competing discourses, which are to be resolved, finalised, and closed. The proposed paradigm suggests a move from competing discourses to what Cools denotes as dialogical creativity. Here we find a set of fundamental interdependencies of what had previously been considered opposites, and further, we acknowledge that these interdependencies are multi-vocal, polyphonic and knotted together. The identity of an individual self or a community can only be understood as a self or community that exists in relationship. Because utterance is a link in a chain of dialogue, choices have to be made about what to say or not say, and whether and when to drop

9 Все религиозные системы, даже примитивные, владеют громадным специальным методологическим аппаратом передачи $и$ истодкования раздичных видов божественного слова (герменевтика), (Bakhtin 1975, 163). I would want to dispute Bakhtin's notion of the primitive, but that is another issue.

10 на овладение вещным, безгласным объектом, не раскрывающим себя в слове, ничего не сообщающим о себе (Bakhtin 1975, 163). 
in or out of conversation, and these choices can always be revised. This is a function of the carnival-like nature of dialogue.

The adaptation of the Cools model to apply to ecclesial or faith communities can be illustrated diagrammatically thus:

\section{Diagram 2}

\begin{tabular}{|l|l|l|}
\hline & First order & Second order \\
\hline Intercultural communication & $\begin{array}{l}\text { Experiences of encounter } \\
\text { with cultural others }\end{array}$ & $\begin{array}{l}\text { Intercultural communica- } \\
\text { tion theory }\end{array}$ \\
\hline Ecumenical dialogue & $\begin{array}{l}\text { Collective experiences of } \\
\text { ecclesial or faith communi- } \\
\text { ties }\end{array}$ & Belief statements/ doctrine \\
\hline
\end{tabular}

In each case, both in intercultural communication and in ecumenical dialogue, the theorising can be understood as a (second order) cultural artefact emerging out of the primary (first order) level of experience and praxis. But for this process to take place we need to accept the underlying quality of uncertainty in all positions held, including our own. We need to accept that uncertainty will characterise not only our present situations, but also (in the form of provisionality) any outcome of dialogue. That is to say, there will be no final outcome understood as a static state, but rather a new, and hopefully creative, moment in the dialectic. This means that any search for finality or 'closure' is not only liable to be totalitarian and therefore ethically problematic, but also philosophically misguided.

Discussion of doctrinal questions (or more broadly, of belief statements) needs to be complemented by a parallel discussion of intercultural questions. I do not, however, want to suggest that doctrinal matters should be overlooked or even given lower priority. They are second order or meta-level issues comparable to intercultural communication theory. My recommendation is that this discussion leads us to understand doctrinal and cultural diversities as standing in a complex mutually interpreting dialectic, and we do ourselves no service in ecumenical dialogue if we overlook this reality. The same point could be made for inter-religious dialogues, but that is a larger discussion.

All language is characterised by the complexities and ambiguities that Bakhtin has identified. Failure to attend to the dialogical nature of language leads, in Bakhtin's words, to transpose 'a symphonic (orchestrated) theme 
on to the piano keyboard' (Bakhtin 1981, 263). ${ }^{11}$ The melody may be recognisable, but something essential has been lost. There is a similar danger if we fail to attend to the nuances of language, not just the technical doctrinal language which forms the focus of most ecumenical dialogue, but the innate complexity of dialogical interaction itself. And we may be left wondering why, when we have seemingly agreed on all the wording, we may still find ourselves puzzled by the deeper-seated problematic of culture.

Bibliography

Ariarajah, S. Wesley

2006 Wider Ecumenism - Current Dialogue 2006, 47. http://wcc-coe.org/ wcc/what/interreligious/cd47-15.html, Accessed 21 January 2013.

\section{Bakhtin, Mikhail}

1975 Вопросы дитературы и Эстетики. Исследования разных лет. Moscow: Хдожественная литература.

1981 The Dialogic Imagination: four essays. Ed. by Michael Holquist. Austin and London: University of Texas Press.

1986 Аитературно-критические Статьи. Moscow: Художественная литература.

\section{Birtill, Geoffrey \& Peter Crediton (eds)}

1996 Anglican-Moravian Conversations: The Fetter Lane Common Statement with Essays in Moravian and Anglican History. London: Council for Christian Unity of the Church of England.

\section{Casey, Edward}

1993 Getting Back into Place: Toward a Renewed Understanding of the PlaceWorld. Bloomington: Indiana University Press.

\section{Cools, Carine}

2011 Relational Dialectics in Intercultural Couples' Relationships. Jyväskylä: University of Jyväskylä.

\section{Lindbeck, George}

1984 The Nature of Doctrine: Religion and Theology in a Post-Liberal Age. London: SPCK.

\section{Louth, Andrew}

1983 Discerning the Mystery: An Essay on the Nature of Theology. Oxford: Clarendon.

11 Он транспонирует симфоническую (оркестрованную) тему на рояль (Bakhtin 1975, 77). 


\section{Maddox, Marion}

1997 How Late Night Theology Sparked a Royal Commission - Sophia: International Journal of Philosophical Theology and Cross Cultural Philosophy of Religion, 36 (2), 111-35.

1998a What is a 'fabrication'? The Political Status of Religious Belief - Australian Religious Studies Review, 2 (1), 5-16.

1998b Religious Belief in the Hindmarsh Island Controversy. - George Couvalis \& Helen Macdonald \& Cheryl Simpson (eds), Cultural Heritage: Values and Rights, 61-79. Adelaide: Centre for Applied Philosophy, Flinders University.

2005 God Under Howard: The Rise of the Religious Right in Australian Politics. Sydney: Allen \& Unwin.

\section{Malouf, David}

2001 A Spirit of Play: The Making of Australian Consciousness. The Australian Broadcasting Commission Boyer Lectures. Sydney: ABC Books.

Meyer, H. (ed.)

1991 Dokumente wachsender Übereinstimmung: sämtliche Berichte und Konsenstexte interkonfessioneller Gespräche auf Weltebene. Paderborn: Bonifatius-Druck.

\section{Oppegaard, Sven \& Gregory Cameron (eds)}

2004 Anglican-Lutheran Agreements: Regional and International Agreements 1972-2002. Geneva: Lutheran World Federation.

\section{Plantinga, Richard J. \& Thomas R. Thompson \& Matthew D. Lundberg}

2010 An Introduction to Christian Theology. Cambridge: Cambridge University Press.

\section{Reid, Duncan}

2012 Identity, Relevance and the Crucified God - Pacifica 25, 258-72.

\section{Ritschl, Dietrich}

1986 The Logic of Theology: A Brief Account of the Relationship between Basic Concepts in Theology. London: SCM. Orig. Zur Logik der Theologie: Kurze Darstellung der Zusammenhänge theologischer Grundgedanken, 1984. München: Chr. Kaiser Verlag.

\section{Strümpfel, Annegreth}

2010 Ökumenisches Lernen in Exil. Zu den Auswirkungen der Mitarbeit Paulo Freires im Ökumenischen Rat der Kirchen - Sören Asmus \& Patrik Mähling \& Simon Paschen \& Annegreth Strümpfel \& Florian Truder (eds), Lernen für das Leben: Perspektiven ökumenischen Lernens und ökumenischer Bildung, 33-48.(Beiheft zur Ökumenischen Rundschau 88.) Frankfurt aM: Otto Lembeck.

\section{Swain, Tony}

1993 A Place for Strangers: Towards a History of Australian Aboriginal Being. Cambridge: Cambridge University Press. 


\section{Tolliday, Phillip}

2010 Ecumenical Theology in Australia: A Negotiation between Hope and Pragmatism - Sören Asmus \& Patrik Mähling \& Simon Paschen \& Annegreth Strümpfel \& Florian Truder (eds), Lernen für das Leben: Perspektiven ökumenischen Lernens und ökumenischer Bildung, 265-74. (Beiheft zur Ökumenischen Rundschau 88.) Frankfurt aM: Otto Lembeck.

Veliko, Lydia \& Jeffrey Gros (eds)

2005 Growing Consensus: church dialogues in the United States, 1962-1991. Washington DC: Bishops' Committee for Ecumenical and Interreligious Affairs, United States Conference of Catholic Bishops.

\section{Williams, Rowan}

2008 Dostoyevsky: Language, Faith, and Fiction. Waco: Baylor University Press. 